\title{
Analysis of morphological characteristics and phenetic relationship of ebony (Diospyros spp.) in Indonesia
}

\author{
RIDESTI RINDYASTUTI ${ }^{1, \bullet}$, LIA HAPSARI ${ }^{1}$, ANJAR TRI WIBOWO ${ }^{2,3, \bullet \bullet}$ \\ ${ }^{1}$ Purwodadi Botanic Gardens, Research Centre for Plant Conservation and Botanic Gardens, Indonesian Institute of Sciences. Jl. Raya Surabaya-Malang \\ Km. 65, Purwodadi, Pasuruan 67163, East Java, Indonesia. Tel.: +62-343-615033, `email: ride17@ gmail.com. \\ ${ }^{2}$ Faculty of Science and Technology, Universitas Airlangga. Jl. Dr. Ir. H. Soekarno, Kampus C, Mulyorejo, Surabaya 60115, East Java, Indonesia. \\ Tel.: +62-31-5936501, Fax.: +62-31-5936502, ^*email: anjar.tri@ @st.unair.ac.id. \\ ${ }^{3}$ Biotechnology of Tropical Medicinal Plants Research Group, Universitas Airlangga. Jl. Dr. Ir. H. Soekarno, Kampus C, Mulyorejo, Surabaya 60115, \\ East Java, Indonesia.
}

Manuscript received: 9 May 2021. Revision accepted: 17 June 2021.

\begin{abstract}
Rindyastuti R, Hapsari L, Wibowo AT. 2021. Analysis of morphological characteristics and phenetic relationship of ebony (Diospyros spp.) in Indonesia. Biodiversitas 22: 2739-2754. Diospyros L. (Ebenaceae) is an economically important genus that covers over 500 plant species. Members of this group are known to produce hard, dark, high-quality timbers known as ebony trees, while other members are known as persimmon trees. There is limited information on the morphological characters and phenetic relationship of this genus from Indonesian archipelago. In this work, we reported the phenetic clustering of 14 species of Indonesian Diospyros, based on plant canopy, stem, leaves, and fruit characters, which was analyzed using UPGMA and Jaccard similarity index. The phenetic dendrogram divided the 14 species of Diospyros into two main clusters which separating Subgen. Maba and Eudiospyros. Further, subgen. Maba was clustered into a single cluster while subgen. Eudiospyros was divided into 3 sub-clusters as sister groups. The clustering in Eudiospyros was supported by low SI and bootstrap value, demonstrating the high morphological variation of the subgenus. The sectional separation of Diospyros spp. was considered as paraphyletic. In general, our phenetic clustering exhibited suitability and relevancy with previous classification. Fruit size and trichomes are very important in this phenetic clustering, especially to form Eudiospyros subgenus. Fruit trichomes were also special characters related to biogeographical distribution following the Wallace line theory.
\end{abstract}

Keywords: Conservation, dendrogram, Diospyros, ebony, species diversity

\section{INTRODUCTION}

Diospyros L. (Ebenaceae) is a plant group that covers important ebony species and persimmons. It is the largest genus of Ebenaceae family that includes over 500 species worldwide with great morphological diversity across Indopacific region (Duangjai et al. 2006; Walnofer 2001; White 1956). Several species belong to this genus, such as $D$. celebica, D. pilosanthera, D. cauliflora, and D. ebenum are known to produce valuable, high-quality timber such as for craft and music instruments (Bennet 2016). Other species such as D. discolor, D. malabarica and D. hasseltii are known to produce edible persimmons, making it an economically important genus (Kinho 2013; Bakhuizen van Den Brink 1937). More recently, many studies revealed medicinal bioactivities of Diospyros species such as antioxidant, anti-inflammatory, analgesic, anti-diabetic (Rauf et al. 2017; Howlader et al. 2012), anti-microbial (Nematollahi et al. 2011), and anti-cancer (Pratiwi and Nurlaeli 2020). Diospyros is dioecious, medium-sized tree rarely shrubs with mostly black and hard bole. Leaves are simple, alternate; inflorescence an axillary cyme, or with the pistil-late flowers solitary. The flowers are green, white or yellow, which are arranged few to many. Corolla is campanulate, salverform, tubular or urceolate, with 3-8 lobes. The stamens number are 2-many, mostly with 4-8 staminodia in pistillate flowers; ovary 3-16 celled. Fruits are large and berry, with persistent calyx, accrescent or not accrescent, and with 1-16 seeds (Duangjai et al. 2006).

On the basis of the monophyly phylogenetic classification using broader samples, Ebenaceae consists of two subfamilies, i.e., Lissocarpoideae and Ebenoideae and four genera Euclea, Royena, Lissocarpa and Diospyros (Duangjai et al. 2006). Among Ebenaceae, Diospyros is the only genus that naturally found in South East Asia including Indonesia. Meanwhile, the other genus Euclea, Royena and Lissocarpa were distributed in outer Asia. Euclea comprises 20 species which are distributed in Africa, Arabia, Socotra and Comoro Island (Retief et al. 2008). The genus Royena comprises 17 species in Africa and the genus Lissocarpa comprises 8 species which are distributed in northwestern South America (Turner et al. 2013).

According to Bakhuizen van den Brink (1936-1955), in South-East Asia and Pacific, Diospyros was divided into 5 subgenera, i.e., subgenus Cargillia, Diospyros (Eudiospyros), Hierniodendron, Maba, and Mabacea. Further, subgenus Eudiospyros was divided into 32 sections while Maba into 4 sections. The species were grouped based on morphological and anatomical characters. This was the last recorded effort to classify Diospyros spp. in South-East Asia and no revision by other 
botanists has been made ever since. Morpho-taxonomical study of Indonesian Diospyros is very limited. Analysis of morphological characters of Diospyros spp. in Indonesia is also firstly reported. Duangjai et al. (2006) analyzed phylogenetic relationship of Ebenaceae sensu lato at subfamily level using plastid DNA sequence data from six regions and reported paraphyletic subfamilial classification (Duangjai et al. 2006). Further, they are suggesting further research with larger plant samples.

Several morpho-taxonomical studies have been conducted in Diospyros, including leaf flushing pattern of some Diospyros spp. (Putri and Chikmawati, 2015), wood anatomy and physical properties of Diospyros blancoi (Krisdianto and Abdurachman, 2005), morphometric differences of fruits, seeds, and pollen grains of some Diospyros spp. in Ukraine (Grygorieva et al. 2013 and Grygorieva et al. 2017), leaf macro and micromorphology of Diospyros spp. in China (Yi et al. 2016), morphology and phenetic relationship of endemic Diospyros spp. in Mascarene Islands (Mauritius) (Venkantasamy et al. 2006). Nevertheless, comprehensive morpho-taxonomic studies that can support taxonomical classification of the genus are still limited, especially for Diospyros that distributed in Indonesia. This study was conducted to support taxonomical, phytogeography and ecological studies of Diospyros distributed in Indonesia. Specifically, in this work we analyzed (i) the phenetic relationship among 14 Diospyros species in Indonesia based on morphological characteristics, (ii) the differentiating characters of each taxon and/or taxon group of Diospyros spp. which contribute to dendrogram construction, and (iii) the floristic distribution patterns in Diospyros spp. based on the biogeographical theory of Indonesian Archipelago.

Here we reported the morphological characters and sectional clustering of 14 Indonesian Diospyros species. We found that the clustering of these Diospyros to be paraphyletic, nevertheless it shows suitability and relevancy with previous plant classification by Bakhuizen van den Brink (1936-1955). Fruit size and fruit trichome were the two most important morphological characteristics in this phenetic clustering, especially to form the cluster of Eudiospyros subgenus. These two characters also demonstrated a strong correlation with the biogeographical distribution of Indonesian Diospyros.

\section{MATERIALS AND METHODS}

\section{Study location}

This study was conducted in Purwodadi Botanic Gardens/PBG, Indonesian Institute of Sciences/LIPI, Pasuruan, East Java, Indonesia. The plant living collections of Diospyros spp. in PBG are located at "vak"/ the code of plant location of "XXG and XXH". The morphological observation was conducted from April 2017 to March 2020 .

\section{Plant materials}

The plant materials investigated in this study were 14 species of Diospyros spp. (Ebenaceae), ex-situ living collections of PBG. It comprises of two subgenera based on the classification by Bakhuizen van den Brink (1936-1955), i.e., Maba and Eudiospyros. Subgen. Maba consisted of two species; whilst subgen. Eudiospyros consisted of 12 species. Further, they belong to some different sections. The plant specimens were mostly originated from Eastern Indonesia, including East Java, South Kalimantan, North Sulawesi, Central Sulawesi, South East Sulawesi, South Sulawesi and Maluku Islands, with 4 endemic species to Kalimantan and Mollucas region. Species list, plant specimen origin, and species distribution were provided in Table 1.

\section{Morphological observation}

Morphological characters, including quantitative and qualitative characters of 1 until 3 plant specimens for each species were observed using plant descriptions by Backhuizen van den Brink (1937; 1938) and the latest identification kit of Diospyros (Ebenaceae) by Ng (1978) for Bornean species. Species identifications were conducted by describing the morphological characters including canopy, stems, branches, leaves, fruits, and fruit calyx. It comprises 57 characters and derived into 193 character states (Table 2).

\section{Data analysis}

Morphological characters were scored using a reference number of " 0 " for characters that were not present in the plant samples and the number of "1" for characters that present in the plant samples. All characters were treated as independent, unordered, and of equal weight. The collected data were analyzed using statistical software PAST (Paleontological Statistics) ver.1.34 by multivariate cluster analysis, unweighted paired group algorithm (UPGMA), and Jaccard similarity index to construct a phenetic dendrogram, with 1000 bootstrap replications. Bootstrap support was categorized as strong $(>85 \%)$, moderate $(70$ $85 \%)$, weak $(50-69 \%)$, and poor, $(<50 \%)$ referring to Kress et al. (2002). Multivariate Jaccard similarity and distance indices were also conducted to generate similarity coefficients among species. Furthermore, analysis of the apomorphy characters (synapomorphy and autapomorphy) were performed to identify the differentiating characters of each operating taxonomic unit (OTU) and/or OTU group of Diospyros spp.

\section{RESULTS AND DISCUSSION}

\section{Phenetic relationship of Diospyros spp.}

Diospyros spp. showed high morphological variation, such as in bark texture, canopy, leaf shape, venation, leaf glands, trichome, leaf flushing, and fruit morphology. Diospyros spp. have various bark texture which ranges from smooth grooved, coarsely grooved, vertically grooved, lenticellate, and lenticellate grooved (Figure 2). 
Table 1. Subgenus, section, species list, plant origin, and distribution of Diospyros spp.

\begin{tabular}{|c|c|c|c|c|}
\hline Subgenus & Section & Species & $\begin{array}{l}\text { Plant specimen } \\
\text { origin }\end{array}$ & Distribution \\
\hline \multirow[t]{2}{*}{$\begin{array}{l}\text { Maba (J. R. et G. } \\
\text { Forst.) Bakh. }\end{array}$} & Forsteria Bakh. & $\begin{array}{l}\text { D. ferrea (Willd.) } \\
\text { Bakh. }\end{array}$ & $\begin{array}{l}\text { Maluku: Seram } \\
\text { Island. }\end{array}$ & $\begin{array}{l}\text { Peninsula Malayana, Sumatra, Java, Borneo, } \\
\text { Philippines, Celebes, Moluccae, Nova Guinea, Nova } \\
\text { Caledonia }\end{array}$ \\
\hline & Miquela Bakh. & $\begin{array}{l}\text { D. andamanica } \\
\text { Bakh. }\end{array}$ & $\begin{array}{l}\text { C. Sulawesi; S. } \\
\text { Kalimantan }\end{array}$ & Peninsula Malayana, Borneo \\
\hline \multirow[t]{12}{*}{$\begin{array}{l}\text { Eudiospyros (L.) } \\
\text { Bakh. }\end{array}$} & $\begin{array}{l}\text { Stelechantha } \\
\text { Bakh. }\end{array}$ & D. cauliflora $\mathrm{Bl}$. & E. Java; Maluku & $\begin{array}{l}\text { Indo China, Sumatra, Java, Lombok, Borneo, } \\
\text { Phillippines, Celebes, Moluccas }\end{array}$ \\
\hline & Ebenaster Bakh. & D. discolor Willd. & East Java & $\begin{array}{l}\text { Philippines, British India, Penninsula Malayana, } \\
\text { Sumatra govt. East. Sumatra, Borneo, Sarawak }\end{array}$ \\
\hline & & $\begin{array}{l}\text { D. amboinensis } \\
\text { Bakh. }\end{array}$ & $\begin{array}{l}\text { Seram Island, } \\
\text { Mollucas }\end{array}$ & Moluccas: Ambon \\
\hline & & D. lolin Bakh. & Mollucas & $\begin{array}{l}\text { Mollucas island (Ambon, Hitoe, Banda, Ceram, } \\
\text { Binoa, Ternate, Halmahera) }\end{array}$ \\
\hline & & D. celebica Bakh. & Sulawesi & Celebes, Manado: Poso \\
\hline & Ptychocylix Bakh. & $\begin{array}{l}\text { D. pilosanthera } \\
\text { Blanco. }\end{array}$ & $\begin{array}{l}\text { Kota Baru, S. } \\
\text { Kalimantan }\end{array}$ & $\begin{array}{l}\text { Pennisula Malayana, Sumatra, Java, Batam, West } \\
\text { Borneo, Phillipines Basilan }\end{array}$ \\
\hline & Nesindica Bakh. & D. javanica Bakh. & $\begin{array}{l}\text { Trenggalek, East } \\
\text { Java }\end{array}$ & Java, Lombok, Timor and Flores \\
\hline & & $\begin{array}{l}\text { D. greshoffiana } \\
\text { Kds. Ex Bakh. }\end{array}$ & S. Sulawesi & Celebes \\
\hline & Glutinosa Bakh. & $\begin{array}{l}\text { D. malabarica } \\
\text { (Desr.) Kostel. }\end{array}$ & $\begin{array}{l}\text { Bogor, Jawa } \\
\text { Barat }\end{array}$ & $\begin{array}{l}\text { Ceylon, India Britanica, Siam, Peninsula Malayana, } \\
\text { P. Langkawi, Sumatra: Lampung, Java, Timor and } \\
\text { Sumbawa, Celebes. }\end{array}$ \\
\hline & Verruculosa Bakh. & D. perfida Bakh. & S. Kalimantan & South East Borneo \\
\hline & Unidentified species & Diospyros sp.1 & North Sulawesi & - \\
\hline & Unidentified species & Diospyros sp.2 & S.E. Sulawesi & - \\
\hline
\end{tabular}

The canopy shape of the genus is generally coneshaped, however, it also displayed other morphological variation that ranges from cone-shape, intermediate, to irregular. The leaf also varies in shape and size. The shape is generally ranging from oval to elliptic, but several species are ovate, obovate, or even ovate-asymmetric shape (Figure 3, Table S1). Further, the leaf glands could be present or absent (Figure 4, Table S1). Fruit characters of Diospyros spp. vary in shape, size, color, groove, and their hairs or trichomes both at mature and dry stages (Figure 5). Several fruit characters are more important than others, such as fruit size, fruit trichomes, and fruit calyx.

Based on the clustering analysis result using UPGMA, we found that the subgenera division of Diospyros by Bakhuizen van den Brink $(1937 ; 1938)$ is monophyletic. The dendrogram of phenetic relationship divided the 14 species of Diospyros into two main clusters which separating Subgen. Maba and Eudiospyros with SI of 21\% and supported by a very strong bootstrap value (100\%); subgen Maba was served as an outgroup. Further, Subgen. $M a b a$ which consists of 2 species, i.e., D. ferrea and $D$. andamanica were clustered with SI of $35 \%$ and weak bootstrap of $67 \%$. Meanwhile, subgen. Eudiospyros was divided into 3 sub-clusters as sister groups although it was supported by poor bootstrap value (33\%), and SI of 26$41 \%$ (Figure 1, Table 3).

In details, within subgen. Eudiospyros, Cluster I consisted of 3 species, i.e., D. perfida, Diospyros sp.2 and D. pilosanthera var. polyalthioides with SI value $33 \%$ and bootstrap of $32 \%$. Cluster II consisted of 3 species, i.e., $D$. cauliflora, D. javanica, and D. greshoffiana with SI of
$30.5 \%$ and bootstrap 9\%. Cluster III consisted of 6 species, which was separated into two sub-clusters i.e $D$. malabarica, D. lolin, D. discolor, and D. amboinensis (subcluster 1); D. celebica and Diospyros sp. (sub-cluster 2) with the SI value of $32 \%$ and bootstrap 14\%. The low SI and bootstrap values were caused by the high variation of morphological characteristics in the subgen. Eudiospyros.

\section{Differentiating morphological characteristics in Diospyros spp.}

Differentiating morphological characteristics in Diospyros spp. which contribute to dendrogram construction of phenetic relationship was produced using the analyses of synapomorphy and autapomorphy characters. Synapomorphy is a derived trait shared by two or more groups of OTU, while autapomorphy is a derived trait that is unique to one OTU (Choudhuri 2014). The analysis of synapomorphy exhibited that the separation between $D$. andamanica and $D$. ferrea in subgen. Maba was supported by 31 characters especially fruit characters, such as fruit diameter $<2 \mathrm{~cm}$, color of young fruit light green but orange when mature, fruit fleshy, trichome absent, fruit surface smooth, fruit calyx with 3 lobes, smooth, thin and leafy. Meanwhile, subgen. Eudiospyros which consist of 12 species were clustered together due to only single character, i.e., the presence of fruit trichomes. This is in accordance with previous grouping of subgen. Eudiospyros by Bakhuizen van den Brink (1936-1955); Eudiospyros means "true Diospyros", it may refer to Diospyros species with one of the characteristic, i.e., the presence of fruit trichomes. 
Table 2. Morphological characteristics of Diospyros spp. observed in this study

\begin{tabular}{|c|c|}
\hline Plant parts & Morphological character and character state \\
\hline Canopy & Canopy shape: cone/pyramidal, cone-irregular, irregular \\
\hline Stem & $\begin{array}{l}\text { Stem color: light brown, dark brown, blackish brown, black, grayish green } \\
\text { Stem surface texture: smoothly grooved, coarsely grooved, vertically grooved, lenticelatte, lenticelatte grooved }\end{array}$ \\
\hline Leaf & 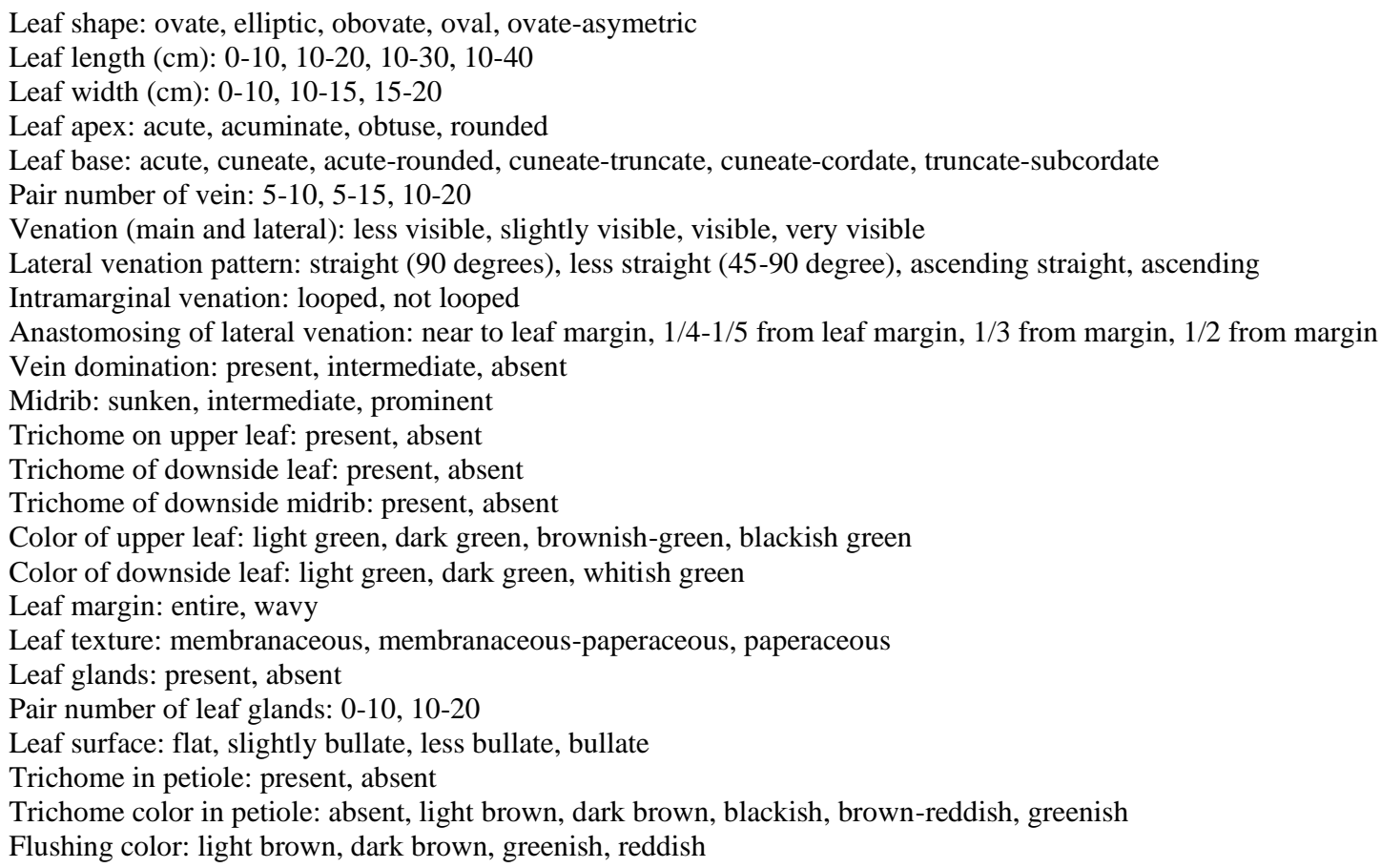 \\
\hline Fruit & $\begin{array}{l}\text { Fruit shape: depressed globose, ellipsoid, ovoid } \\
\text { Fruit diameter }(\mathrm{cm}):<2,2-5,5-10,>10 \\
\text { Fruit length }(\mathrm{cm}):<1,1-2,2-5,5-10 \\
\text { Color of young fruit: light green, dark green, yellow } \\
\text { Fruit flesh: not fleshy, intermediate, fleshy } \\
\text { Fruit groove: present, absent } \\
\text { Wooden fruit: present, absent } \\
\text { Fruit apex: acute, obtuse flat, depressed obtuse } \\
\text { Trichome of young fruit: present, absent } \\
\text { Trichome density of young fruit: absent, not dense, dense } \\
\text { Trichome color of young fruit: absent, brown, golden brown, orange, silvery green } \\
\text { Trichome of mature fruit: present, absent } \\
\text { Trichome density of mature fruit: absent, not dense, dense } \\
\text { Trichome color of mature fruit: absent, light green, dark green, reddish-brown } \\
\text { Fruit surface: smooth, lenticellate, dense hairy } \\
\text { Color of dry fruit: brown, black, red } \\
\text { Mature fruit dry: smooth, wrinkle, decayed, drying hard wooden }\end{array}$ \\
\hline
\end{tabular}

Fruit calyx Shape of fruit calyx: campanulate, simple round shape, bowl shape, isodiametric, flatten triangularly Fruit calyx diameter $(\mathrm{cm}):<1,1-2,2-4,4-6 \mathrm{~cm}$

Length of fruit calyx lobes $(\mathrm{cm}):<1,1-2,2-4$

Number of fruit calyx lobes: $3,4,4-5$

Shape of fruit calyx lobes: acute triangular, acuminate triangular, triangular

Fruit calyx position of young fruit: flat, half-covering, whole covering, spreading

Fruit calyx position of mature fruit: half-covering, whole covering, reflexed

Calyx lobes margin: entire, reflexed, wavy

Texture of fruit calyx: thin leafy, thick leafy, woody

Thickness of fruit calyx: thin, thick

Surface of fruit calyx: smooth, dense hairy, smooth lenticellate, coarsely lenticellate 
Cluster I of subgen. Eudiospyros consists of 3 species, i.e., D. perfida, Diospyros sp.2 dan D. pilosanthera var. polyalthioides. It possessed 20 synapomorphy characters, such as leaf shape ovate and elliptic with leaf length 10-30 $\mathrm{cm}$ and width $0-15 \mathrm{~cm}$, fruit shape globose with diameter $2-5 \mathrm{~cm}$ and length $2-5 \mathrm{~cm}$, color of young fruit light green, trichome of young and mature fruit present. D. cauliflora, D. javanica dan D. greshoffiana were grouped in cluster II because they are supported by 19 synapomorphic characters such as leaf shape oval, width $0-10 \mathrm{~cm}$, lateral venation are ascending, vein domination present, trichome of upper leaf absent, trichome of downside leaf absent, leaf margin entire, leaf texture membranaceous, leaf glands absent, fruit diameter $<2 \mathrm{~cm}$, length $1-2 \mathrm{~cm}$, fruit has no groove and with nonwoody pericarp, fruits are hairy to densely hair, with fruit calyx lobes $<1 \mathrm{~cm}, 4$-lobed, flat and thick. Whilst, cluster III which consist of 6 species, i.e., $D$. malabarica, D. lolin, D. discolor, D. amboinensis, D. celebica, and Diospyros sp. have morphological similarities on 7 characters such as trichome at downside of leaf and petiole leaf, trichome of young and mature fruit and shape of fruit calyx lobes.

Moreover, sub-cluster 1 in cluster III shared similarities of 16 characters, such as leaf trichome present in upper, downside and petiole, fruit trichome present, and fruit calyx 4-lobed with acute triangular shape. Whereas, the 3 of 4 species in this cluster, i.e., D. lolin, D. discolor, and D. amboinensis grouped in sect. Ebenaster, while $D$. malabarica grouped in sect. Glutinosa. Result from this study implies further outlook to the sect. Glutinosa, especially by describing the lesser-known member of this section such as D. pseudomalabarica Bakh., D. koeboeensis Bakh., D. britanno-borneensis Bakh., D. eburnea Bakh., and D. siamensis Hochr. The placement revision of $D$. malabarica into other section could be established if it is supported by sufficient evidence.

Some autapomorphic characters were also identified in this study and became key characters for each Diospyros species. D. ferrea is one of species included in subgen. Maba; it has smooth fruit surface and 3-lobed fruit calyx, this species was also especially characterized by very small fruit ( $<1 \mathrm{~cm}$ in diameter). $D$. javanica was characterized by silvery-green trichomes of young fruit. The specimen of $D$. pilosanthera has paperaceous leaf and reddish leaf flushing, which are very important characteristics distinguishing this species from the others. Further, this species is considered as the variant of polyalthioides. Variant of polyalthioides has a larger fruit calyx than $D$. pilosanthera (6 $\mathrm{cm}$ in diameter) with very wavy calyx lobes, while $D$. pilosanthera has smaller and simpler calyx lobes (1.5-2 cm in diam.). However, D. pilosanthera var. polyalthioides is considered as the synonim of $D$. polyalthioides. $D$. lolin has truncate-subcordate leaf base and reddish-brown trichome of mature fruit. D. malabarica has leaf venation that anastomosing $1 / 2$ from leaf margin and has isodiametric 4-lobed fruit calyx. D. discolor has leaf with $10-40 \mathrm{~cm}$ long, fruit diameter $>10 \mathrm{~cm}$, and orange trichome of young fruit. D. amboinensis has $10-20 \mathrm{~cm}$ wide leaf with slightly bullate surface. Whilst, one unidentified species of Diospyros sp.1 has lenticellate grooved bark, ovate-asymmetric leaf, yellow young fruit with reflexed fruit calyx.

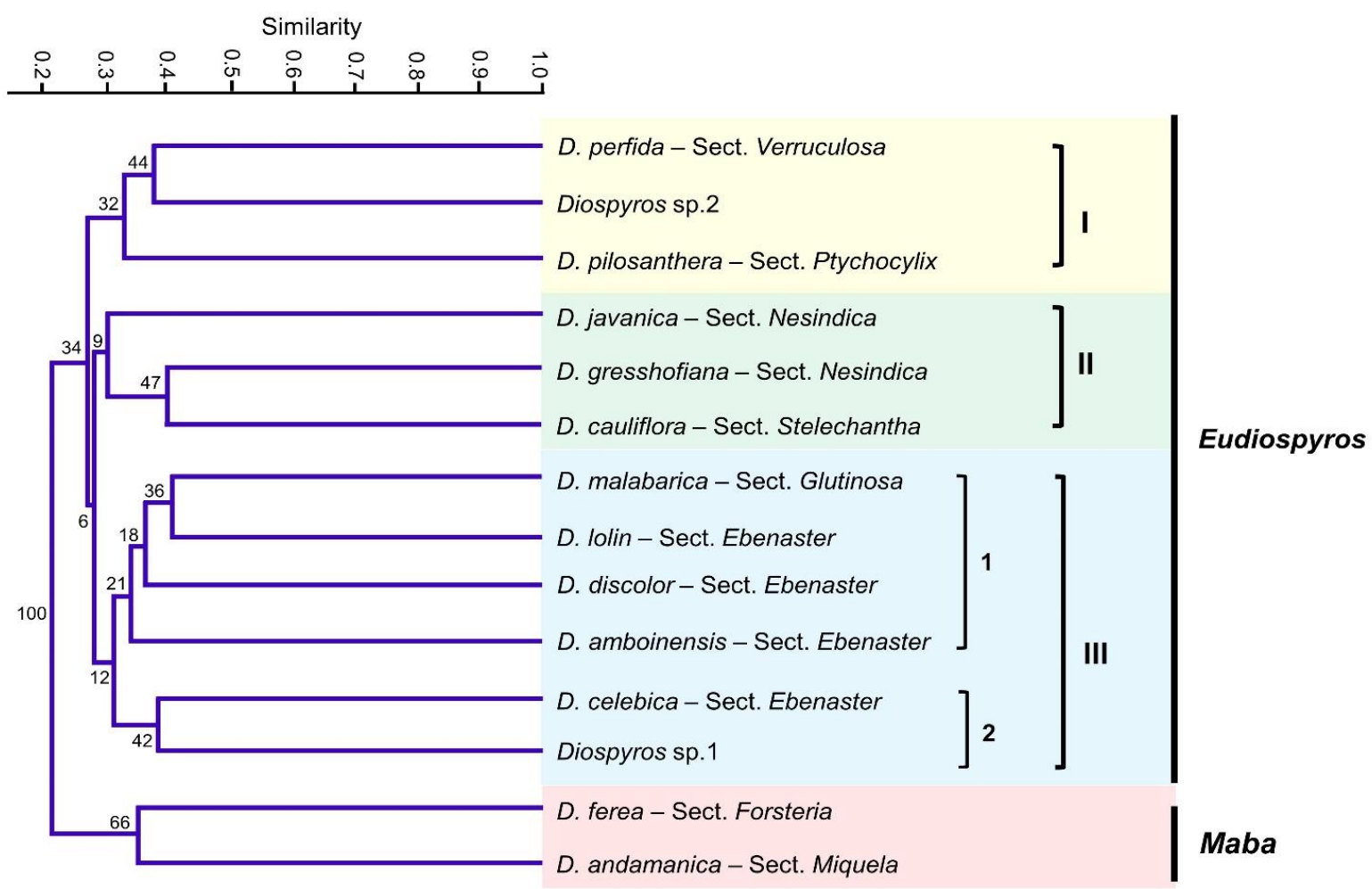

Figure 1. Dendrogram of phenetic relationship of 14 species of Diospyros spp. in Indonesia using Jaccard Similarity Index. 
Tabel 3. Similarity index (\%) among 14 species of Diospyros spp.

\begin{tabular}{|c|c|c|c|c|c|c|c|c|c|c|c|c|c|c|c|}
\hline No. & Species name & D1 & D2 & D3 & D4 & D5 & D6 & D7 & D8 & D9 & D10 & D11 & D12 & D13 & D14 \\
\hline D1 & D. ferrea & 100 & & & & & & & & & & & & & \\
\hline $\mathrm{D} 2$ & D. andamanica & 34.83 & 100 & & & & & & & & & & & & \\
\hline D3 & D. cauliflora & 15.84 & 32.22 & 100 & & & & & & & & & & & \\
\hline D4 & D. discolor & 16.35 & 19.42 & 17.65 & 100 & & & & & & & & & & \\
\hline D5 & D. amboinensis & 20.41 & 22.45 & 28.57 & 31.52 & 100 & & & & & & & & & \\
\hline D6 & D. lolin & 21.00 & 23.00 & 25.00 & 37.78 & 39.08 & 100 & & & & & & & & \\
\hline D7 & D. celebica & 14.56 & 23.71 & 28.57 & 30.11 & 29.67 & 28.72 & 100 & & & & & & & \\
\hline D8 & D. pilosanthera & 15.69 & 20.00 & 21.88 & 22.22 & 20.41 & 24.74 & 26.88 & 100 & & & & & & \\
\hline D9 & D. javanica & 29.67 & 27.66 & 32.95 & 21.00 & 24.21 & 28.72 & 28.26 & 15.69 & 100 & & & & & \\
\hline $\mathrm{D} 10$ & D. greshoffiana & 17.65 & 28.42 & 40.00 & 35.16 & 25.00 & 33.70 & 34.83 & 30.43 & 27.66 & 100 & & & & \\
\hline D11 & D. malabarica & 14.15 & 28.13 & 36.36 & 34.78 & 31.52 & 40.91 & 30.11 & 27.37 & 28.72 & 29.47 & 100 & & & \\
\hline $\mathrm{D} 12$ & D. perfida & 21.43 & 31.52 & 32.58 & 24.49 & 25.26 & 27.08 & 26.60 & 32.22 & 26.60 & 34.44 & 37.08 & 100 & & \\
\hline D13 & Diospyros sp.1 & 11.21 & 19.80 & 29.67 & 35.56 & 29.35 & 35.56 & 38.37 & 26.60 & 21.43 & 32.97 & 34.07 & 25.00 & 100 & \\
\hline D14 & Diospyros sp.2 & 20.20 & 21.00 & 26.88 & 22.00 & 29.35 & 27.08 & 32.22 & 33.71 & 25.26 & 32.97 & 24.49 & 37.93 & 34.83 & 100 \\
\hline
\end{tabular}

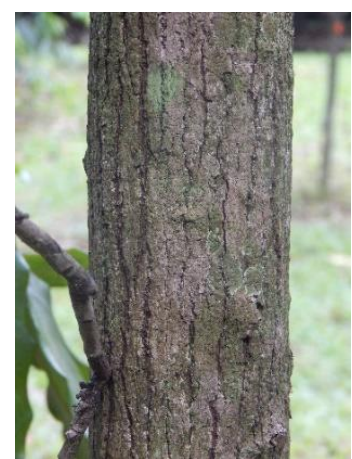

A

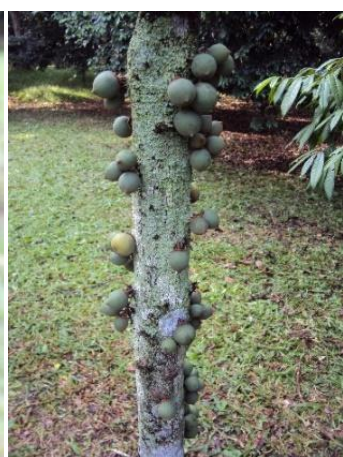

B

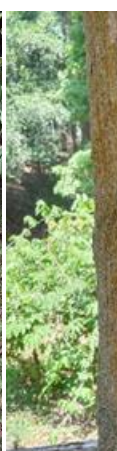

1,9

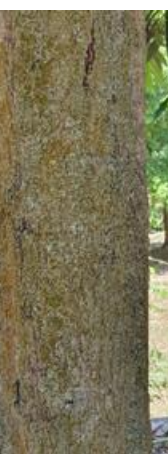

C

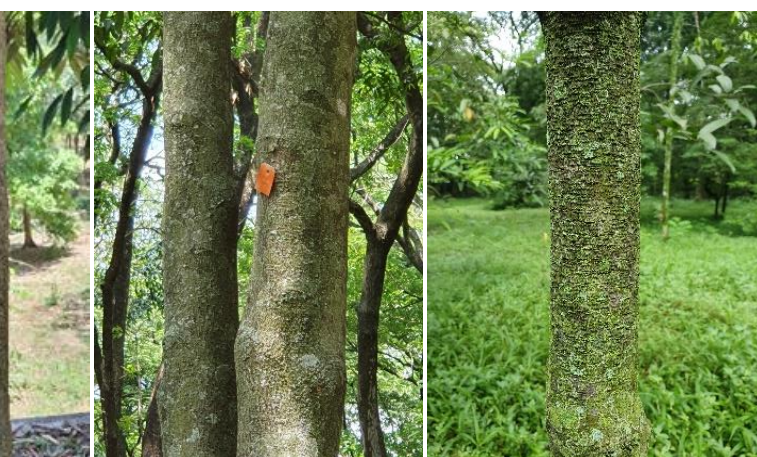

D

E

Figure 2. Variation of bark surface: A. Vertically grooved bark of $D$. amboinensis, B. Coarsely grooved bark with cauline fruit of $D$. cauliflora C. Smoothly grooved bark of D. celebica, D. Lenticellate bark of D. perfida, E. Lenticellate grooved bark of $D$. greshoffiana.

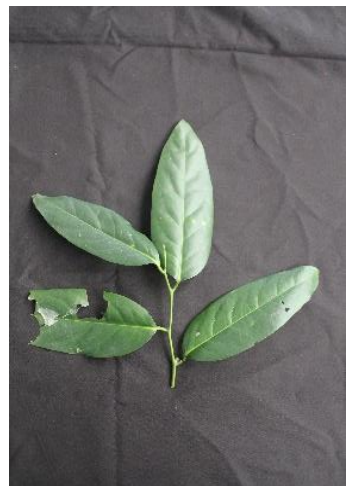

A

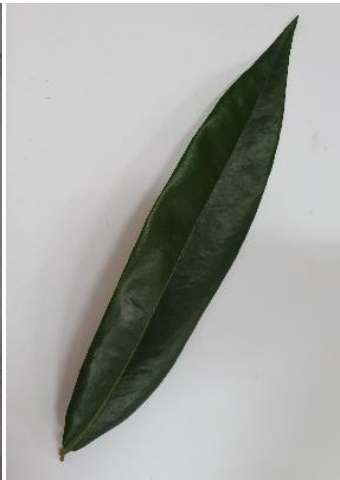

B

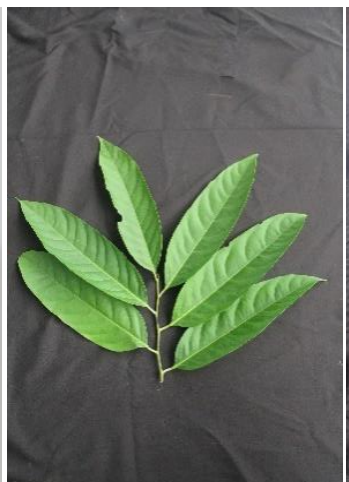

C

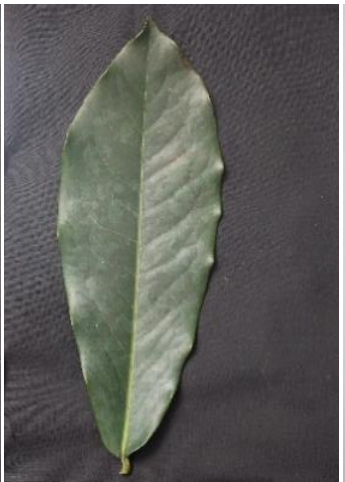

D

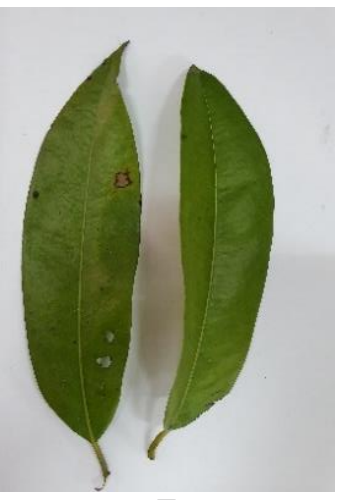

$\mathbf{E}$

Figure 3. Variation of leaf shape in Diospyros spp.: A. Ovate leaf of D. javanica B. Elliptic-lanceolate leaf of D. celebica, C. Ovallanceolate leaf of $D$. cauliflora, D. Obovate leaf of D. amboinensis E. Ovate-asymmetric leaf of Diospyros sp.1 


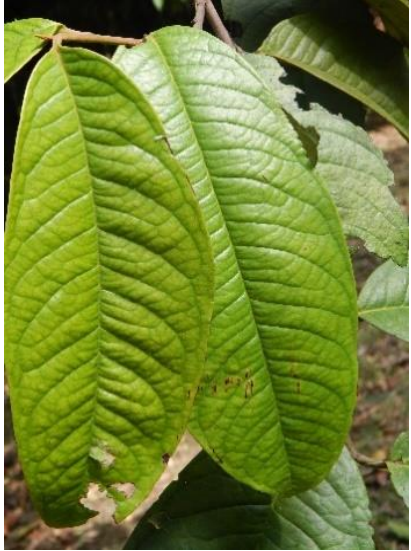

A

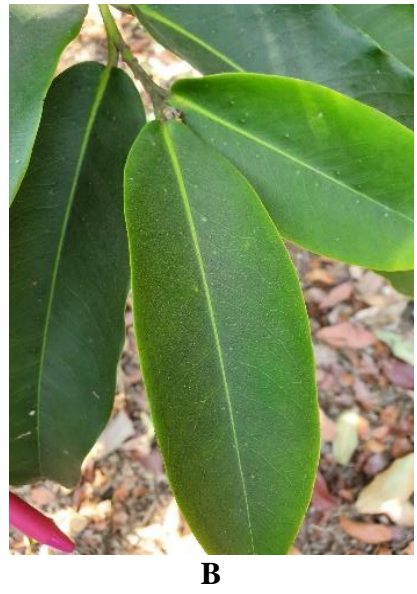

$\mathbf{B}$
Figure 4. Variation of leaf glands: A. The absence of leaf glands in D. pilosanthera, B. The presence of leaf glands in D. discolor

\section{Key to the species of Diospyros spp.}

\section{Diospyros L.}

Trees rarely shrubs, evergreen, dioecious, small to medium-sized trees $5-40 \mathrm{~m}$ height, conus/pyramidal to irregular canopy, hard bole with bark brownish, greyish to black. Leaves are simple, alternate, $12-40 \mathrm{~cm}$ long, 2.5-20 $\mathrm{cm}$ wide, membranaceous, paperaceous to coriaceous, trichome in upper and/or downside, leave base cuneate, round to sub-heartshaped, leaf apex acute to acuminate; inflorescence an axillary cyme, or with the pistil-late flowers solitary. Flowers are green, white or yellow, which are arranged few to many; corolla campanulate, salverform, tubular or urceolate, with 3-8 lobes; stamens number 2many, mostly with 4-8 staminodia in pistillate flowers; ovary 3-16 celled. Fruits large and berry, with persistent calyx, accrescent or not accrescent; 3-5 lobes; flat, reflexed, wavy margined, spreading; leafy to woody; thin to thick; clasping the whole fruit and shorten with age or not, and with 1-16 seeds.

1. Medium sized-tree up to $10 \mathrm{~m}$, bole straight, canopy conusshaped, leaves alternate, elliptic, lanceolate to elliptic, leaves $12-40 \mathrm{~cm}$ long, $2.5-20 \mathrm{~cm}$ width, membranaceous, paperaceous to coriaceous, smooth in upper leaf, trichome at downside, leave base cuneate, round to sub-heartshaped, leaf apex acute to acuminate.

a. bole black and hard, young trees with very leafy and conus-shaped canopies, leaves lanceolatte to elliptic

b. young trees not leafy, canopy shape conus/pyramidal to irregular, leaves elliptic to oval
2. a. leaves large, $12-40 \mathrm{~cm}$ long, $2.5-20 \mathrm{~cm}$ width, elliptic to obovate, margin wavy, bullate surface, fruit size around 10 $\mathrm{cm}$ in diameter

b. leaves large or medium, leaf margin entire

D. amboinensis

3. a. leaves medium size $10-20 \mathrm{~cm}$ long, $3-10 \mathrm{~cm}$ wide, fruit cauline, fruit $1.3-2 \mathrm{~cm}$ in diameter .............. D. cauliflora b. leaves $10-20 \mathrm{~cm}$ long, $3-10 \mathrm{~cm}$ wide, fruit noncauline

4. a. leaves alternate, oval to elliptic, $12-40 \mathrm{~cm}$ long, $2.5-20 \mathrm{~cm}$ width, leaves margin entire, fruits $10 \mathrm{~cm}$ in diameter, globose to depressed globose, densely orange to brown fruit trichome

D. discolor b. leaves alternate, elliptic-oval, leaves and fruit with smallsize

5. a. fruits $7 \mathrm{~cm}$ in diameter, dark green when young, yellow when mature, covered by brown trichomes and easily removed trichome, acute triangular lobes of fruit calyx ......... D. lolin b. Fruits smaller than $5 \mathrm{~cm}$ in diameter, covered by trichomes

6. a. Leaf alternate, elliptic, lanceolate, oval, $12-20 \mathrm{~cm}$ long, 2.5$10 \mathrm{~cm}$ width, fruits $4-5 \mathrm{~cm}$ in diameter, globose, covered by brown trichomes, fruit calyx is large, $4-6 \mathrm{~cm}$ in diameter ...................................... malabarica b. fruits large or small, globose or ellipsoid

7. a. leaf alternate, elliptic-oval, ovate, $12-20 \mathrm{~cm}$ long, $2.5-10 \mathrm{~cm}$ width, fruits $4-5 \mathrm{~cm}$ in diameter, globose, covered by brown trichomes, fruit calyx clasping the whole fruits and shorten with age D. perfida b. leaf alternate, elliptic-oval, $12-20 \mathrm{~cm}$ long, $2.5-10 \mathrm{~cm}$ width, fruits less than $4 \mathrm{~cm}$ in diameter, covered by dense brown trichomes, fruit calyx not clasping and shortened by age

8. a. Fruit with dense light brown trichome, simple and flat fruit calyx D. greshoffiana b. Fruit smaller, fruit calyx slightly reflexed to reflexed or spreading

9. a. fruit covered by dense silvery trichomes, lobes fruit calyx slightly reflexed .............................. D. javanica b. lobes of fruit calyx reflexed, margin wavy expanded to 4-6 $\mathrm{cm}$ in diameter, fruit covered by dense light brown trichomes

D. pilosanthera var. polyalthioides

10. a. fruits $1.5-2 \mathrm{~cm}$ in diameter, ellipsoid, green when young, fruit surface smooth and lenticellate, fleshy, orange when mature

D. andamanica b. fruits $1.5-2 \mathrm{~cm}$ in diameter, ellipsoid, green when young, fruit surface smooth, fleshy, orange when mature

D. ferrea 


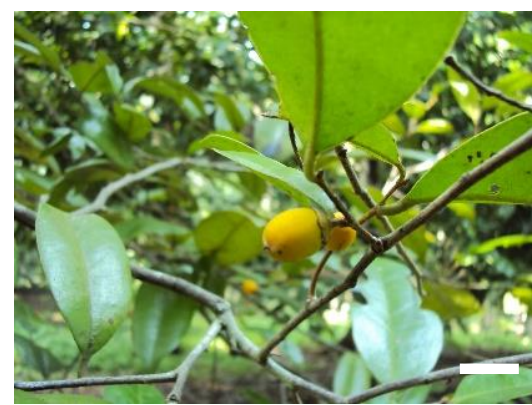

A

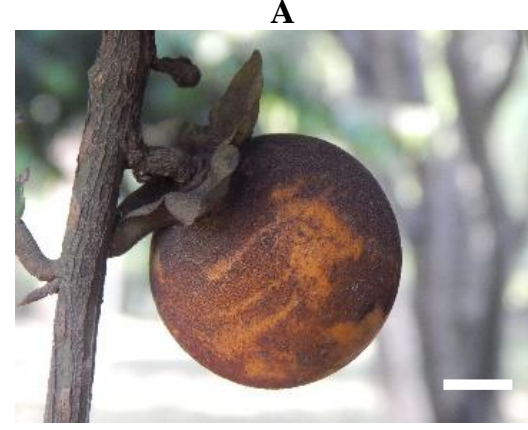

D

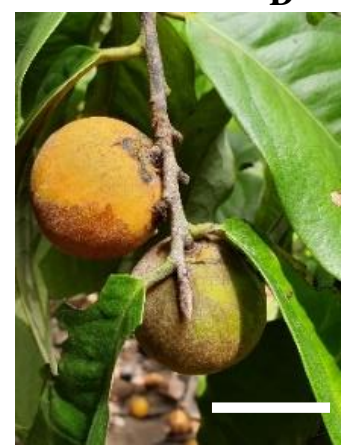

G

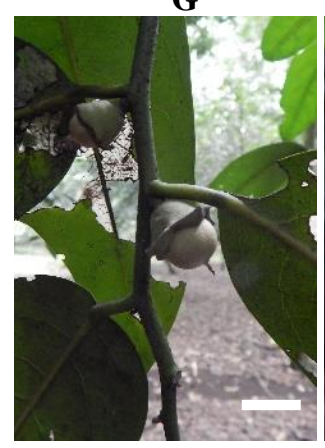

$\mathbf{K}$

H

$\mathbf{L}$

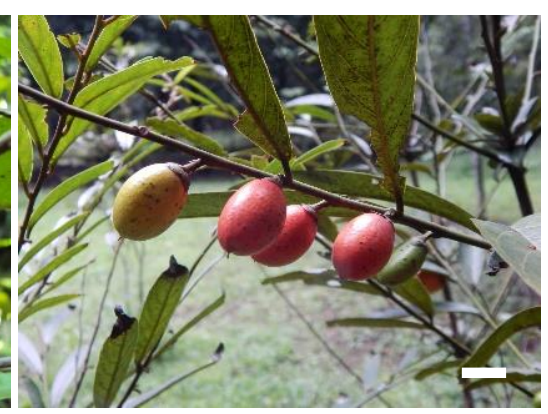

B

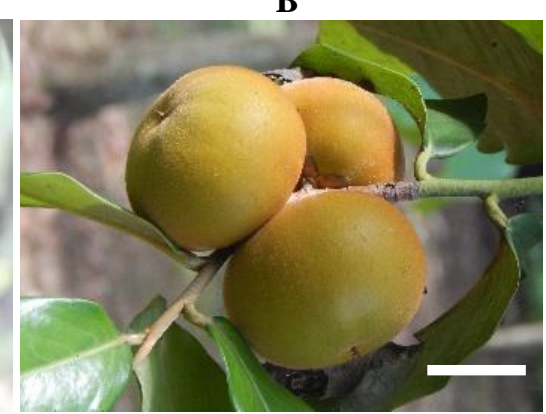

$\mathbf{E}$
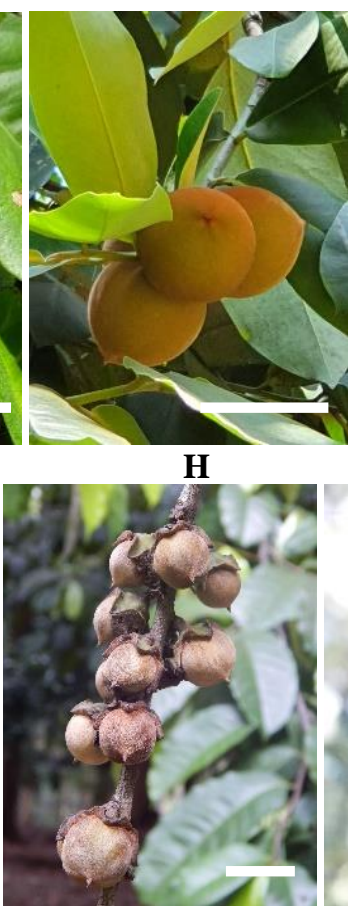

M

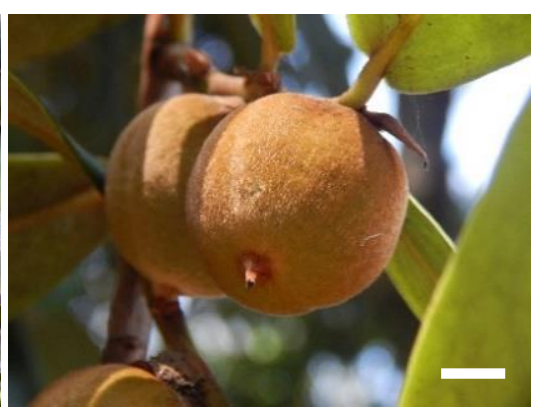

C

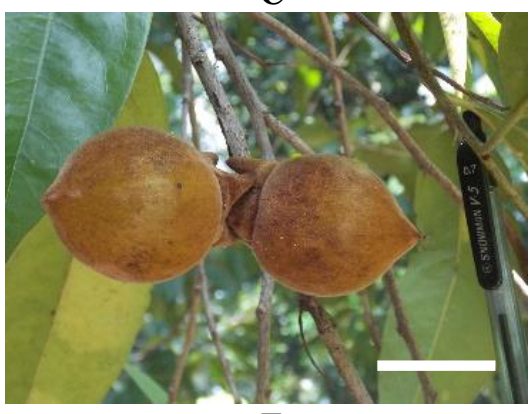

F
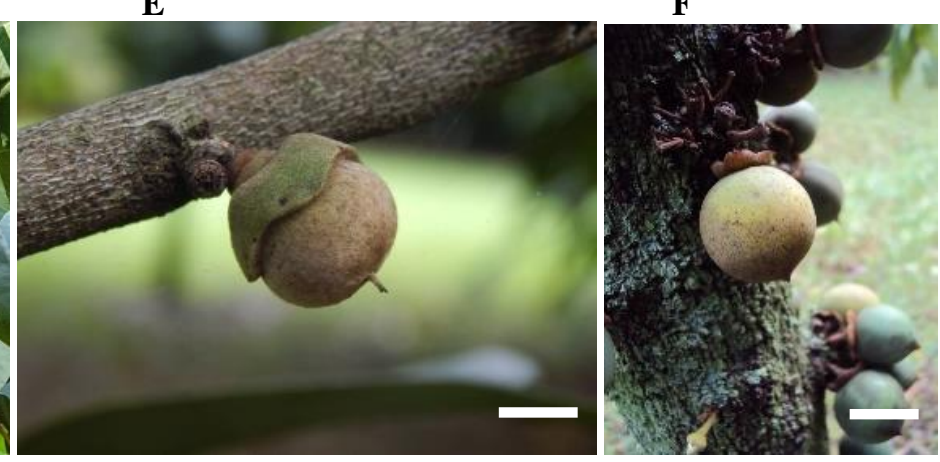

J

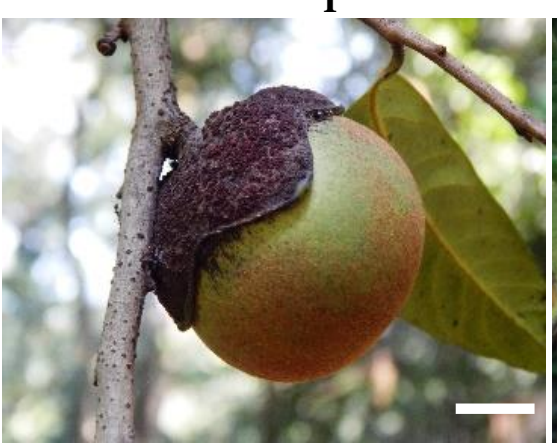

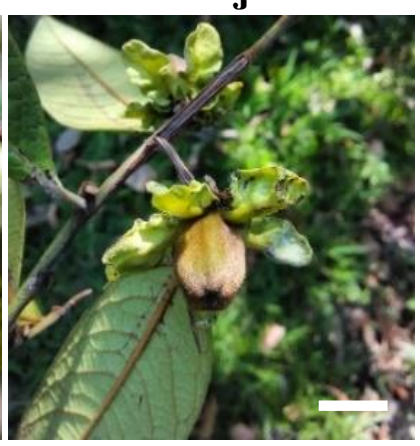

N

Figure 5. Fruit and fruit calyx characteristics of Diospyros spp.: A. D. ferrea, B. D. andamanica, C. D. celebica, D. D. malabarica, E. D. amboinensis F. Diospyros sp.1 G. D. lolin, H. D. discolor, I. D. greshoffiana, J. D. cauliflora K. D. javanica L. Diospyros sp.2, M. D. perfida, and N. D. pilosanthera var. polyalthioides. Scale bar: A, B, C, D, I, J, K, M, N =1 cm, E, F, G, H = $10 \mathrm{~cm}, \mathrm{~L}=2 \mathrm{~cm}$

\section{Discussion}

Phenetic relationship and morphological characters

The living collections of Diospyros spp. were characterized by referring to some previous morphological descriptions by Bakhuizen van den Brink (1937; 1938) which described Diospyros species of South East Asia and $\mathrm{Ng}$ (1978) described species of Borneo, Putri and Chikmawati (2015) studied leaf flushing characters, also Gosline (2009) and Provance et al. (2008) described new species of Cameroon and Mesoamerica, respectively. Plant morphological characters used in this study included canopy characters, the details of venation, the presence of leaf glands, trichome characters, leaf flushing characters, and fruit flesh and groove characters both in a fresh and dry stage. Flowers were not characterized in this study because of the absence of female or bisexual plants in the collection. Fruit calyx is generally small or large, flat or spreading, leafy or woody textured, flat or reflexed, entire 
or wavy margined, and growing in unique and special features such as clasping the whole fruits when young then shorten with age, like in $D$. perfida. This characters is important for species identification because it is distinctive for species level (Rindyastuti, 2021).

Sectional separation of Diospyros spp. resulted in this study is considered as paraphyletic; since some different sections were clustered together and not clearly separated. However, in general, our phenetic clustering of Diospyros spp. support previous plant classification of Diospyros spp. of South East Asian region by Backhuizen van den Brink (1936-1955), especially in the sect. Ebenaster (cluster III), with the exception of D. malabarica (sect. Glutinosa) which nested into this cluster. Likewise, sect. Verruculosa nested into cluster I together with sect. Ptychoclyx; whilst sect. Stelechantha nested with sect. Nesindica in cluster II. This finding could serve as a new reference to sectional separation in classification of Diospyros spp. in South East Asia especially in Indonesian archipelago.

Differentiating morphological characteristics in Diospyros spp. which contribute to phenetic dendrogram construction was produced using the analyses of synapomorphy and autapomorphy characters. From the analyses of synapomorphy and automorphy, it revealed that some vegetative and generative characteristics are important for taxonomical grouping and clustering, such as leaf size, leaf margin, and details of venation. Fruit size and trichomes are two generative characters that significantly determine the dendrogram clustering of this taxa. According to Liu and Qin (2013) fruit morphology of plant family is useful characters in taxonomy. Trichomes are epidermal organs briefly introduced to have physiological functions such as in reflectance, energy balance, sun protection, drought resistance, gas exchange, insect, and disease resistance (Xiao et al. 2017). Trichomes showed taxonomical significance in many plant groups such as Cucurbitaceae, Rosaceae, Prunus spp. (Yang et al. 2018; Wang et al. 2019), Phlomoides (Lamiaceae) (Seyedi and Salmaki, 2015), Ballota (Lamiaceae) (Osman, 2012), Convolvulaceae (Ashfaq et al. 2019), etc. Vegetative trichome varies in size, type, number, density, etc., genetically encoded by specific genes (Yang et al. 2018) and serve as a taxonomical determinant (Creller and Werner, 1996). Whilst, study on generative trichomes such as fruit trichomes are still limited (Xue et al. 2018), therefore, this study results will provide a start point in understanding the morphology, development, functions and significance of generative trichomes in plants. In Diospyros group, generative trichome characters could be investigated in detail for the colors, densities and microstructures.

Other important characters from this analysis are fruit calyx shape. Persistent fruit calyx is one of rare morphological characters in plants introduced to protect the developing fruit from predators as well as from desiccation.Its variation is often correlated with differences in dispersal methods. Fruit calyces vary from inflated, accrescent to non-accrescent (Deanna et al. 2019). Persistent fruit calyx including its diverse and modified morphological characteristics is regulated by specific genes (Pei et al. 2016; Deanna et al. 2019). In Diospyros spp., fruit calyx is a specific characteristic to species identities that serve as important characters for species identification (Rindyastuti, 2021), therefore it has less relevance to differentiating characters for dendrogram clustering or taxonomical classification to infra-specific level, i.e., section or genera level.

The study results also indicated that Diospyros could be recognized not only from morphological characteristics of generative organs, but also vegetative organs, such as the shape and size of leaf, leaf surface, details in venation, and the characters of leaf trichomes. According to Hickey and Wolfe (1975), vegetative plant organs could serve as a good species determinant which provides strong evidence for taxonomical study in Dicotyledoneae. Diospyros spp. is slow grower and dioecious with separated male and female plants in one species which leads to difficulties in observing complete generative characters and conducting species identification. This could be resolved by developing identification method using vegetative characters. The availability of taxonomical system using morphological characteristics of vegetative organs is very important for practical identification of this taxa.

\section{Suggestion of species identity}

Two species of Diospyros sp. analyzed in this study are identified into the genus level. Morphological descriptions of these species are difficult to support identification until species level. However, the clustering dendrogram showed that Diospyros sp. 1 grouped with the other 4 species from the sect. Ebenaster in the cluster III sub-cluster 2, thus this species is possibly classified into sect. Ebenaster. Diospyros sp.1 was characterized to have globose fruits, with $5 \mathrm{~cm}$ in diameter, fruit surface is densely velvet and reddish-brown colored while fruit calyx is woody and erect. Furthermore, Diospyros sp. 1 has high morphological similarities with D. celebica, by possessing 32 synapomorphic characters. The leaf length is $10-30 \mathrm{~cm}$ with $0-10 \mathrm{~cm}$ wide, lateral venation pattern ascending, intramarginal venation with no looped, upper leaf are smooth, downside leaf are hairy, leaf flushings are greenish, fruits are ellipsoid, mature fruit is light browncolored, fruit is intermediate fleshy, fruit pericarp is hard or woody, and fruit surface is dark green that turning to brown trichomes when mature. However, the erect and densely haired fruit calyx exhibited that this specimen is different from a well-known endemic species to Celebes, $D$. celebica.

Diospyros sp.2 is another unidentified species that showed high similarity with $D$. javanica and $D$. greshoffiana, it is closely related to $D$. venenosa which are distributed at Sulawesi. However, this unidentified specimen has globose fruit with $1.5-2 \mathrm{~cm}$ in diameter with pistil residual, while $D$. venenosa has depressed globose fruit with $1-2 \mathrm{~cm}$ long and $1.5-3 \mathrm{~cm}$ in diameter. On the basis of the dendrogram analysis, this unidentified specimen grouped into Cluster I together with $D$. perfida and $D$. pilosanthera var. polyalthioides. Thus, this species could be identified as one of the species of sect. Nesindica, Ptychocylix or Verruculosa. Further examination subjected to both unidentified species compared to larger specimens 
of Diospyros spp. is required to support species identification.

\section{Implications to biogeographical distribution}

The biogeographic pattern of plant species in the Indonesian archipelago is characterized by the abundance of narrowly distributed species, where some species are often endemic to an island. Among the species of Diospyros studied, there are several endemic species, such as $D$. perfida which is endemic to Kalimantan, D. celebica and $D$. greshoffiana which endemic to Sulawesi and $D$. amboinensis which endemic to Mollucas (Figure 6) (Bakhuizen van den Brink 1937; Rindyastuti 2021). Generally, biogeographical distribution of plants leads to the variation of plant morphology even to speciation (Tan et al. 2020). Wallace's line theory underlined that the species from Kalimantan are generally separated from the species from Sulawesi and East Indonesia, i.e., Mollucas and Papua (Michaux 2010). The flora of western Indonesia has different morphological characters from the species distributed in the eastern part such as Sulawesi and Maluku (Culmsee and Leuschner 2013). However, Ebenaceae is a small plant family that may show but considered not to dominate this separating pattern (Van Welzen and Slik 2009). The outlook to biogeographical distribution and morphological variation of Diospyros species throughout Indonesian archipelago will provide more information for this taxa.
Based on the dendrogram analysis, the species which are distributed in Kalimantan i.e. D. pilosanthera var. polyalthioides and $D$. perfida (cluster I) tends to be separated from the species that are distributed in Java, Sulawesi and Mollucas Islands (cluster II and III). The species distributed in Sulawesi esp. the endemic species ( $D$. celebica and D. gresshofiana), have special characters differentiating them from the species distributed in the western of Indonesia, especially Kalimantan, i.e. the thick, velvety but not easily removed fruit trichomes. The species distributed in Kalimantan have quite dense sometimes short trichomes that easily removed by age (D. perfida, and $D$. pilosanthera var. polyalthioides).

The biogeographic pattern of native plant species, especially those with narrow and endemic distribution areas, can also indicate the ecological characteristics of plant habitats (Nuzhyna and Gaydarzhy 2015; Pyakurel and Wang 2013). Habitat of Diospyros spp. in Kalimantan such as mixed dipterocarp forest is characterized by wetter climate, which is very different from drier habitat in Sulawesi with edaphic karst environments that often lead to water stress. Habitat differences correlated with differences in leaf morphology, where Diospyros spp. from Sulawesi developed a more persistent and denser fruit trichome. A dense trichome is able to reduce transpiration rate at warmer temperature or sun-exposed area as an adaptation form to water shortage conditions (Perez-estrada et al. 2000; Morandi et al. 2007; Salehi-Lisar and Bakhshayeshan-Agdam, 2016; Pyakurel and Wang, 2013).

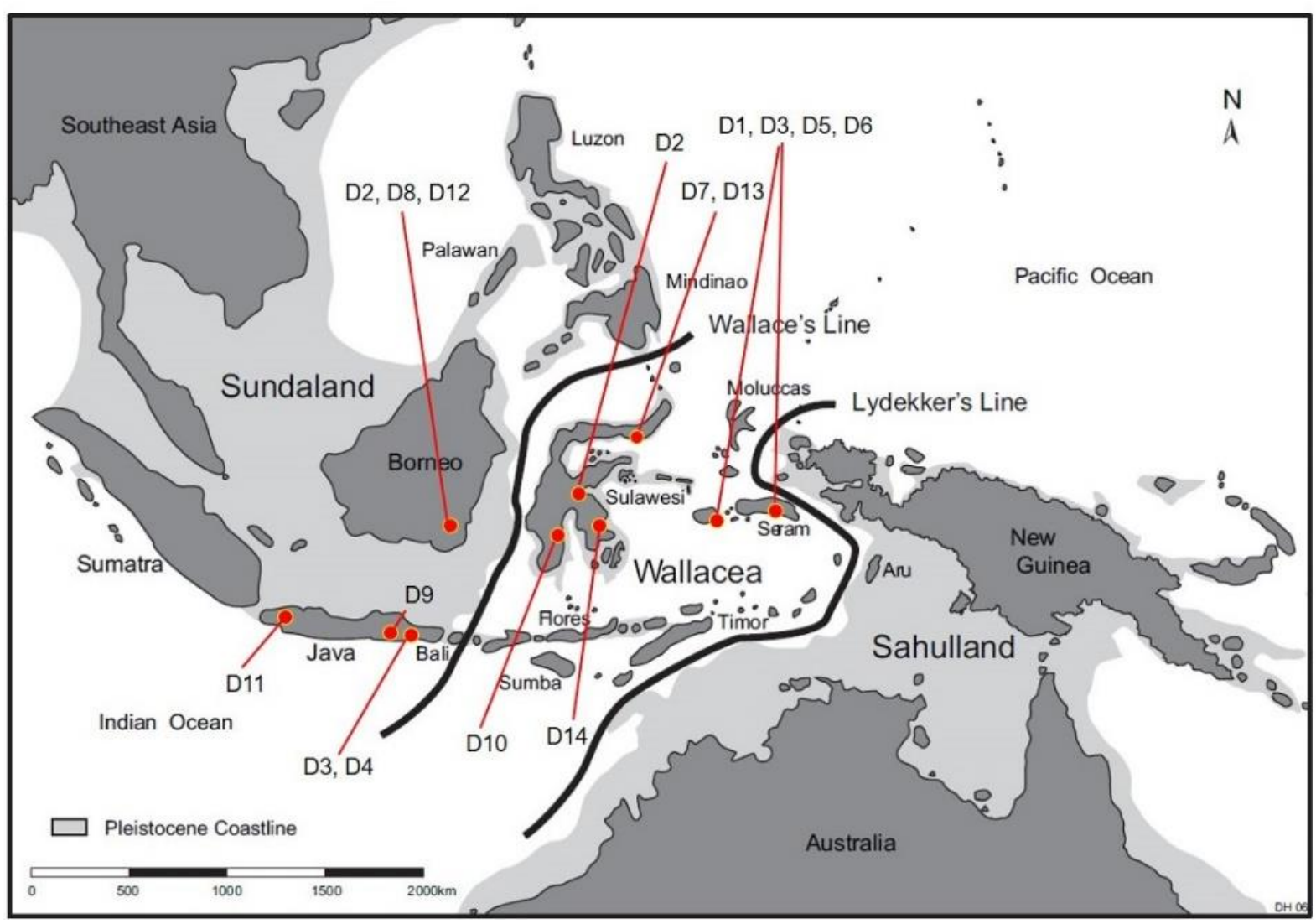

Figure 6. Biogeographic distribution of 14 species of Diospyros spp. examined in this study. 


\section{ACKNOWLEDGEMENTS}

The authors would like to acknowledge Purwodadi Botanic Gardens, Indonesian Institute of Sciences for providing the living plant materials. Sincere thanks were also addressed to Matrani, Abdul Goni, Dwi Narko for the technical assistance, and Destario Metusala for valuable scientific discussions during the study.

\section{REFERENCES}

Ashfaq S, Ahmad M, Zafar M, Sultana S, Bahadur S, Ullah F, Zaman W, Ahmed SN, Nazish M. 2019. Foliar micromorphology of Convolvulaceous species with special emphasis on trichome diversity from the arid zone of Pakistan. Flora 255: 110-124.

Bakhuizen van den Brink RC. 1937. Revisio Ebenacearum Malayensium. Bulletin Jard. Bot. Buitenzorg serie III. XV².

Bakhuizen van den Brink RC. 1938. Revisio Ebenacearum Malayensium. Bulletin Jard. Bot. Buitenzorg serie III. XV³.

Bakhuizen van den Brink RC. 1936-1955. Revisio Ebenacearum Malayensium. Bulletin du Jardin Botanique de Buitenzorg, se`rie 315 (1-5): 1-515.

Bennett BC. 2016. The Sound of Trees: Wood Selection in Guitars and Other Chordophones. Economic Botany 70: 49-63. DOI: 10.1007/s12231-016-9336-0

Choudhuri S. 2014. Bioinformatics for Beginners: Genes, genomes, molecular evolution, databases and analytical tools. Publisher: Elsevier.

Culmsee H, Leuschner C. 2013. Consistent patterns of elevational change in tree taxonomic and phylogenetic diversity across Malesian mountain forests. J Biogeogr 40 (10): 1997-2010. DOI: 10.1111/jbi. 12138

Creller MA and Werner DJ. 1996. Characterizing the novel fruit surface morphology of 'Marina' peach using scanning electron microscopy. Journal of the American Society for Horticultural Science 121 (2): 198-203. DOI: 10.21273/JASHS.121.2.198.

Deanna, R., M. D. Larter, G. E. Barboza, and S. D. Smith. 2019. Repeated evolution of a morphological novelty: a phylogenetic analysis of the inflated fruiting calyx in the Physalideae tribe (Solanaceae). Am J Bot 106 (2): 270-279. DOI: 10.1002/ajb2.1242

Duangjai S, Wallnofer B, Samuel R, Munzinger J and Chase M. 2006 Generic delimitation and relationships in Ebenaceae sensu lato: Evidence from Six Plastid DNA Region. Am J Bot 93(12): 18081827. DOI: 10.3732/ajb.93.12.1808.

Hickey LJ and Wolfe JA. 1975. The bases of Angiosperm phylogeny. Annals of the Missouri Botanical Garden 62 (3): 538-589. DOI $10.2307 / 2395267$.

Howlader MSI, Rahman MM, Kalhipa ABR, Ahmed F and Rahman MM 2012. Antioxidant and Antidiarrhoeal Potentiality of Diospyros blancoi. International Journal of Pharmacology 8 (5): 403-409.

Kinho J. 2013. The ability of adaptation and early growth of nine types of Diospyros in ex-situ conservation in North Sulawesi. in: Langi M, Tasirin JS, Walangitan HJ, Masson,G. (eds). Proceeding of International Conference on Forest and Biodiversity. Indonesia: Manado Forestry Research Institute. [Indonesian]

Krisdianto A. 2005. Anatomical and physical properties of Bisbul wood (Diospyros blancoi A.DC.). J For Res 2 (1): 57 - 67. DOI: 10.20886/ijfr.2005.2.1.57-67

Lestarini W, Sulasmi, Matrani, Fauziah, Trimanto, Fiqa AP. 2012. An alphabetical list of plant species cultivated in Purwodadi Botanic Gardens. Purwodadi Botanic Gardens. [Indonesian]

Gosline G. 2009. Diospyros korupensis $\mathrm{sp}$. nov. and Diospyros onanae $\mathrm{sp}$ nov. (Ebenaceae) from Cameroon. Nord J Bot 27: 353-358. DOI: 10.1111/j.1756-1051.2009.00555.x

Grygorieva O, Brindza J, Ostrovský R, Klymenko S, Grabovetsk O. 2013. Pollen characteristics in some Diospyros species. Modern Phytomorphology 3: 45-50. DOI:10.5281/zenodo.161593

Grygorieva O, Klymenko S, Vergun O, Hudz N, Nikolaieva N, Schubertová Z, Palamarchuk O, Brindza J. 2017. Morphologica characteristics and determination of volatile organic compounds of
Diospyros virginiana L. genotypes fruits. Potravinarstvo Slovak Journal of Food Sciences 2017 (1): 612-622. DOI: 10.5219/808.

Liu B, H-N Qin. 2013. Taxonomic revision of the Symplocos nakaharae complex (Symplocaceae) with special reference to fruit morphology. Journal of Systematics and Evolution 51 (1): 94-114. DOI: 10.1111/j.1759-6831.2012.00223.x

Nematollahi A, Aminimoghadamfarouj N, Wiart C. 2011. Anti-bacterial, Antioxidant activity and Phytochemical study of Diospyros wallichii an Interesting Malaysia's endemic species of Ebenaceae. International Journal of PharmTech Research 3 (3): 1732-1736.

Michaux B. 2010. Biogeology of Wallacea: geotectonic models, areas of endemism, and natural biogeographical units. Biological Journal of the Linnean Society 101: 193-212. DOI: 10.1111/j.10958312.2010.01473.x

Morandi B, Losciale P, Manfrini L, Zibordi M, Studhalter M and Grappadelli MC. 2007. The growth of the kiwifruit in its final stages. Proc. VIth IS on Kiwifruit Eds. A.R. Ferguson et al. Acta Hort. 753, ISHS

Osman, AK. 2012. Trichome micromorphology of Egyptian Ballota (Lamiaceae) with emphasis on its systematic implication. Pak J Bot 44: 33-46.

Perez-estrada LB, Cano-santana Z and Oyama K. 2000. Variation in leaf trichomes of Wigandia urens: environmental factors and physiological consequences. Tree Physiology 20: 629-632. DOI: 10.1093/treephys/20.9.629.

Pei, M., Niu, J., Li, C. et al. 2016. Identification and expression analysis of genes related to calyx persistence in Korla fragrant pear. BMC Genomics 17: 132 DOI: 10.1186/s12864-016-2470-3.

Pratiwi RA, Y Nurlaeli. 2020. Screening of plant collection of Cibodas Botanic Gardens, Indonesia with anticancer properties. Biodiversitas 21 (11): 5186-5229. DOI: 10.13057/biodiv/d211125

Putri EK and Chikmawati T. 2015. Leaf flushing as taxonomic evidence of some Diospyros species. Floribunda 5 (2): 31-47. DOI: 10.32556/floribunda.v5i2.2015.127.

Provance MC, Ruiz IG and Sanders AC. 2008. The Diospyros salicifolia complex (Ebenaceae) in Mesoamerica. Journal of the Botanical Research Institute of Texas 2 (2): 1009-1100.

Pyakurel A and Wang JR. 2013. Leaf morphological variation among paper birch (Betula papyrifera Marsh.) genotypes across Canada. Open Journal of Ecology 3 (4): 284-295.

Ng F SP. 1978. Ebenaceae. In F. S. P. Ng [ed.]. Tree flora of Malaya, vol. 3, 56-94. Longman, London, UK.

Nuzhyna NV, Gaydarzhy MM. 2015. Comparative characteristics of anatomical and morphological adaptations of plants of two subgenera Haworthia Duval to arid environmental conditions. Acta Agrobotanica 68 (1): 23-31.

Rauf A, Uddin G, Patel S, Khan A, Halim SA, Bawazeer S, Ahmad K, Muhammad N, Mubarak MS. 2017. Diospyros, an under-utilized, multi-purpose plant genus: A review. Biomedicine \& Pharmacotherapy 91: 714-730.

Retief E, Siebert SJ, and van WYK. 2008. A new species of Euclea (Ebenaceae) from ultramafic soils in Sekhukhuneland, South Africa, with notes on its ecology. Bothalia 38(1): 31-37.

Rindyastuti R. 2021. Conservation of Diospyros spp. (Ebenaceae) in Purwodadi Botanic Gardens, Indonesia, with an outlook on carbon storage. IOP Conf Ser: Earth Environ. Sci 724012038.

Soepadmo E, Saw LG, Chung RCK. 2002. Tree Flora of Sabah and Sarawak. Perpustakaan Negara Malaysia.

The Plant List. 2020. http://www.theplantlist.org/tpl1.1/record/kew2770361.

Turner, B, Munzinger J, Duangjai S, Temsch EM, Stokenhuber R, Barfuss MHJ, Chase MW, Samuel R. 2013. Molecular phylogenetics of New Caledonian Diospyros (Ebenaceae) using plastid and nuclear markers. Mol Phylogenet Evol 69: 740-763. DOI: 10.1016/j.ympev.2013.07.002.

Van Welzen PC, Slik JWF 2009. Patterns in species richness and composition of plant families in the Malay Archipelago. Blumea 54: 166-171. DOI: 10.3767/000651909X475969

Venkatasamy S, Khittoo G, Nowbuth P and Vencatasamy DR. 2006. Phylogenetic relationships based on morphology among the Diospyros (Ebenaceae) species endemic to the Mascarene Islands. Bot J Linn Soc 150: 307-313. DOI: 10.1111/j.10958339.2006.00474.x. 
Walnofer B. 2001. The biology and systematics of Ebenaceae : A review. Annalen des Naturhistorischen Museums in Wien. Vienna: 418-512.

White F. 1956. Distribution of the African species of Diospyros. Journal of Plant Taxonomy and Geography 11 (1): 525-540. DOI: 10.1080/00837792.1956.10669649

Salehi-Lisar SY, Bakhshayeshan-Agdam H. 2016. Drought Stress in Plants: Causes, Consequences, and Tolerance. Drought Stress Tolerance in Plant 1: 1-16. DOI: 10.1007/978-3-319-28899-4 1

Seyedi Z and Salmaki Y. 2015. Trichome morphology and its significance in the systematics of Phlomoides (Lamiaceae; Lamioideae Phlomideae). Flora - Morphology, Distribution, Functional Ecology of Plants 213: 40-48.

Tan K, Lu T, Ming-Xun R. Biogeography and evolution of Asian Gesneriaceae based on updated taxonomy. PhytoKeys 157: 726. DOI: $10.3897 /$ phytokeys. 157.34032
Wang D-J, Zeng J-W, and Ma W-T. 2019. Morphological and structural characters of trichomes on various organs of Rosa roxburghii. HORTSCIENCE 54 (1):45-51. DOI: 10.21273/HORTSCI13485-18.

Yang S, Cai Y, Liu X, Dong M, Zhang Y, Chen S, Zhang W, Li Y, Tang M, Zhai X, Weng Y, and Ren H. 2018. A CsMYB6-CsTRY module regulates fruit trichome initiation in cucumber. Journal of Experimental Botany 69 (8): 1887-1902. DOI: 10.1093/jxb/ery047.

Yi Z, Qiao JJ, Lu GY, Wu G, Xie GY, Qin MJ. 2016. Identification of six species of medicinal Diospyros plants based on leaf macro- and micro-morphology. Zhongguo Zhong Yao Za Zhi 41 (21): 3942-3949. DOI: $10.4268 /$ cjcmm20162110.

Xiao K, Mao X, Lin Y, Xu H, Zhu Y, Cai Q, Xie H, Zhang J. 2017. Trichome, a Functional Diversity Phenotype in Plant. Molecular Biology 6 (1): 6

Xue S., Dong, M., Liu, X. et al. 2019. Classification of fruit trichomes in cucumber and effects of plant hormones on type II fruit trichome development. Planta 249: 407-416. 10.1007/s00425-018-3004-9 
Table S1. Morphological characteristic of 14 Diospyros species in Indonesia

\begin{tabular}{|c|c|c|c|c|c|c|c|c|}
\hline No. & Che. & D1 & D2 & D3 & D4 & D5 & D6 & D7 \\
\hline 1 & $\mathrm{BC}$ & Black & Light brown & Dark brown & Light brown & Blackish brown & Black & Blackish brown \\
\hline 2 & BT & Smooth grooved & Smooth grooved & Coarsely grooved & Vertically grooved & Vertically grooved & Vertically grooved & Vertically grooved \\
\hline 3 & CS & Irregular & Conus-irregular & Conus-irregular & Conus & Conus & Conus & Conus \\
\hline 4 & LS & Ovate, oval-elliptic & Elliptic, oblong & Elliptic, oblong & $\begin{array}{l}\text { Ovate, oval, elliptic, } \\
\text { oblong }\end{array}$ & $\begin{array}{l}\text { Elliptic, obovate, } \\
\text { ovate }\end{array}$ & $\begin{array}{l}\text { Elliptic, ovate, } \\
\text { obovate }\end{array}$ & Elliptic, lanceolate \\
\hline 5 & LL & $4-8.5 \mathrm{~cm}$ & $10-22 \mathrm{~cm}$ & $9-27 \mathrm{~cm}$ & $11-33 \mathrm{~cm}$ & $15-32 \mathrm{~cm}$ & $10-34 \mathrm{~cm}$ & $19.1-23.4 \mathrm{~cm}$ \\
\hline 6 & LW & $2-5 \mathrm{~cm}$ & $2.8-5.7 \mathrm{~cm}$ & $3-6.3 \mathrm{~cm}$ & $5-15 \mathrm{~cm}$ & $10-15 \mathrm{~cm}$ & $4.5-15 \mathrm{~cm}$ & $4.13-5.1 \mathrm{~cm}$ \\
\hline 7 & LA & Obtuse, rounded & Acute & Acuminate & Short acuminate & Acute & Acute, short acuminate & Acute-acuminate \\
\hline 8 & LB & Acute & Acute-cordate & Cuneate & $\begin{array}{l}\text { Acute, subcordate, } \\
\text { Cordate, rounded }\end{array}$ & Truncate, subcordate & $\begin{array}{l}\text { Acute, rounded, } \\
\text { subcordate }\end{array}$ & Cuneate - truncate \\
\hline 9 & PNV & 5-7 pairs & 7-11 pairs & 10-12 pairs & 10-22 pairs & 11-17 pairs & 12-14 pairs & 15 - 20 pairs \\
\hline 10 & V & Less visible & Visible & Visible & Slightly visible & Visible & More visible & Slightly visible \\
\hline 11 & LVP & Less straight & Ascending-straight & Ascending & Ascending-straight & Ascending & Straight (900) & Ascending \\
\hline 12 & IV & Looped & no looped & Looped & no looped & Looped & Looped & no looped \\
\hline 13 & M & Sunken above & Intermediate sunken & Prominent above & Intermediate sunken & Sunken above & Intermediate sunken & Intermediate sunken \\
\hline 14 & ALV & $1 / 3$ from leaf margin & $\begin{array}{l}\text { Very near leaf } \\
\text { margin }\end{array}$ & $\begin{array}{l}1 / 4 \text { to } 1 / 5 \text { from leaf } \\
\text { margin }\end{array}$ & $1 / 3$ from leaf margin & $1 / 3$ from leaf margin & $1 / 3$ from leaf margin & $\begin{array}{l}1 / 4 \text { to } 1 / 5 \text { from leaf } \\
\text { margin }\end{array}$ \\
\hline 15 & VD & Intmd & Present & Present & Absent & Present & Present & Absent \\
\hline 16 & TUL & Absent & Absent & Absent & Absent & Absent & Absent & Absent \\
\hline 17 & TDL & Absent & Absent & Absent & Present & Present & Present & Present \\
\hline 18 & TDM & Present & Present & Absent & Present & Absent & present & Present \\
\hline 19 & CUL & Blackish green & Dark green & Dark green & Brownish green & Dark green & Brownish green & Light green \\
\hline 20 & $\mathrm{CDL}$ & Dark green & Light green & Light green & Dark green & Dark green & Dark green & Whittish green \\
\hline 21 & LM & Entire & Entire & Entire & Entire & Wavy & Wavy & Entire \\
\hline 22 & LT & Membranaceous & Membranaceous & Membranaceous & Membranaceous & Membranaceous & Membranaceous & $\begin{array}{l}\text { Membranaceous- } \\
\text { paperaceous }\end{array}$ \\
\hline 23 & LG & Absent & Present & Absent & Present & Present & Present & Absent \\
\hline 24 & PNLG & 0 & 7-12 pairs & 0 & 9-16 pairs & 4-6 pairs & 4-6 pairs & 0 \\
\hline 25 & LS & Bullate & Flat & Bullate & Flat & Slightly bullate & Bullate & Flat \\
\hline 26 & $\mathrm{TP}$ & Present & Present & Absent & Present & Present & Present & Present \\
\hline 27 & TCP & Light brown & Reddish brown & Absent & Dark brown & Blackish & Light brown & Light brown \\
\hline 28 & LFC & Light brown & Light brown & Light brown & Greenish & Light brown & Light brown & Greenish \\
\hline 29 & FS & Globose & Ellipsoid & Ovoid-globose & $\begin{array}{l}\text { Globose-depressed } \\
\text { globose }\end{array}$ & Globose & Globose & Ellipsoid-globose \\
\hline 30 & FD & $0.8-1.3 \mathrm{~cm}$ & $1.6-1.9 \mathrm{~cm}$ & $1.5-2 \mathrm{~cm}$ & $8-13 \mathrm{~cm}$ & $7-11 \mathrm{~cm}$ & $4.5-6 \mathrm{~cm}$ & $1.93-2.92$ \\
\hline
\end{tabular}




\begin{tabular}{|c|c|c|c|c|c|c|c|c|}
\hline 31 & FL & $0.95-1.5 \mathrm{~cm}$ & $2-2.7 \mathrm{~cm}$ & $1.5-1.9 \mathrm{~cm}$ & $6-9 \mathrm{~cm}$ & $6-9 \mathrm{~cm}$ & $4.5-5 \mathrm{~cm}$ & $1.63-3.27 \mathrm{~cm}$ \\
\hline 32 & CYF & Light green & Light green & Dark green & Dark green & Light green & Light green & Light green \\
\hline 33 & $\mathrm{CMF}$ & Orange & Orange & Yellow & Orange & Orange & Orange & Light brown \\
\hline 34 & $\mathrm{FF}$ & Fleshy & Fleshy & intmd & Intmd & Non fleshy & Intmd & Intmd \\
\hline 35 & FG & Absent & Absent & Absent & Absent & Absent & Absent & Present \\
\hline 36 & WF & Absent & Present & Present & Absent & Absent & Present & Present \\
\hline 37 & FA & Obtuse flat & Obtuse flat & Acute & Depressed obtuse & Depressed obtuse & Obtuse flat & Acute \\
\hline 38 & TYF & Absent & Absent & Present & Present & Present & Present & Present \\
\hline 39 & TDYF & Absent & Absent & Dense & Dense & Dense & Not dense & Dense \\
\hline 40 & TMF & Absent & Absent & Present & Present & Present & Present & Present \\
\hline 41 & TDMF & Absent & Absent & Not dense & Not dense & Not dense & Not dense & Dense \\
\hline 42 & TCYF & Smooth & Smooth & Lenticelate & Dense hairy & Smooth & Dense hairy & Dense hairy \\
\hline 43 & TCMF & Absent & Absent & Light green & Dark green & Light green & Reddish brown & Dark green \\
\hline 44 & FS & Smooth & Smooth & Lenticelate & Dense hairy & Smooth & Dense hairy & Dense hairy \\
\hline 45 & $\mathrm{CDF}$ & Red & Brown & Brown & Red & Brown & black & Black \\
\hline 46 & MF & Decayed & Wrinkle & Wrinkle & Decayed & Smooth & Decayed & Smooth \\
\hline 47 & SFC & Bowl shape & Simple round shape & Simple round shape & Flatten triangular & Flatten triangular & Flatten triangular & Flatten triangular \\
\hline 48 & FCD & $0.7-0.8 \mathrm{~cm}$ & $1-1.4 \mathrm{~cm}$ & $2-2.5 \mathrm{~cm}$ & $4 \mathrm{~cm}$ & $2.5-3 \mathrm{~cm}$ & $2 \mathrm{~cm}$ & $2-2.2 \mathrm{~cm}$ \\
\hline 49 & LFCL & $0.7-0.8 \mathrm{~cm}$ & $1-1.4 \mathrm{~cm}$ & $2-2.5 \mathrm{~cm}$ & $4 \mathrm{~cm}$ & $2.5-3 \mathrm{~cm}$ & $2-2.3 \mathrm{~cm}$ & $2-2.2 \mathrm{~cm}$ \\
\hline 50 & NFCL & Lobes 3 & Lobes 3 & Lobes 4 & Lobes 4 & Lobes 4 & Lobes 4 & Lobes 4 \\
\hline 51 & SFCL & Triangular bunga & Acute triangular & Acute triangular & Acute triangular & Acute triangular & Acute triangular & Acute triangular \\
\hline 52 & FCPMF & Half-covering & Flat & Flat & Flat & Flat & Flat & Flat \\
\hline 53 & FCPYF & Flat & Flat & Flat & Flat & Flat & Flat & Flat \\
\hline 54 & CLM & Entire & Entire & Entire & Wavy & Entire & Reflexed & Entire \\
\hline 55 & $\mathrm{TFC}$ & Thin leafy & Thin leafy & Woody & Woody & Thin leafy & Woody & Thin leafy \\
\hline 56 & TFC & Thin & Thin & Thick & Thick & Thin & Thick & Thin \\
\hline 57 & SFC & Smooth & Smooth & Hairy & Coarsely lenticellate & Hairy & hairy & Hairy \\
\hline
\end{tabular}


Table S1. Morphological characteristic of 14 Diospyros species in Indonesia (con't)

\begin{tabular}{|c|c|c|c|c|c|c|c|c|}
\hline No. & Che. & D8 & D9 & D10 & D11 & D12 & D13 & D14 \\
\hline 1 & $\mathrm{BC}$ & Light brown & Blackish brown & Light brown & Blackish brown & Dark brown & Grayish green & Light brown \\
\hline 2 & BT & Smooth grooved & Smooth grooved & Lenticellate & Smooth grooved & Smooth grooved & Lenticellate grooved & Lenticellate \\
\hline 3 & CS & Conus-irregular & Irregular & Conus & Conus-irregular & Conus-irregular & Conus & Conus \\
\hline 4 & LS & Elliptic, obovate & Elliptic, oval, ovate & $\begin{array}{l}\text { Elliptic, ovate, } \\
\text { obovate }\end{array}$ & $\begin{array}{l}\text { Elliptic, oval, ovate, } \\
\text { obovate }\end{array}$ & Elliptic, ovate & $\begin{array}{l}\text { Elliptic, oval, ovate, } \\
\text { obovate }\end{array}$ & $\begin{array}{l}\text { Elliptic, oval, ovate, } \\
\text { obovate }\end{array}$ \\
\hline 5 & LL & $11-28 \mathrm{~cm}$ & $10-22 \mathrm{~cm}$ & $10-24 \mathrm{~cm}$ & $8-21 \mathrm{~cm}$ & $12-30 \mathrm{~cm}$ & $15-27 \mathrm{~cm}$ & $16-24.5 \mathrm{~cm}$ \\
\hline 6 & LW & $4.5-11 \mathrm{~cm}$ & $3-7.5 \mathrm{~cm}$ & $4.5-8.5 \mathrm{~cm}$ & $3.5-8 \mathrm{~cm}$ & $4-11 \mathrm{~cm}$ & $4.5-8.5 \mathrm{~cm}$ & $6-11 \mathrm{~cm}$ \\
\hline 7 & LA & Acute & Acute & $\begin{array}{l}\text { Acute, short } \\
\text { acuminate }\end{array}$ & Short acuminate & Acuminate & Acuminate & Acute \\
\hline 8 & LB & Cuneate & Acute-rounded & Cuneate & $\begin{array}{l}\text { Cunneate, cordate, sub } \\
\text { cordate }\end{array}$ & Acute-rounded & Cuneate & Acute \\
\hline 9 & PNV & 12-14 pairs & 7-10 pasang & 8-11 pairs & $9-12$ pairs & 7-10 pairs & 8-12 pairs & 6-9 pairs \\
\hline 10 & V & More visible & Slightly visible & Slightly visible & Visible & Visible & Visible & Visible \\
\hline 11 & LVP & Straight (900) & Ascending & Ascending & Less straight & Ascending & Ascending & Ascending \\
\hline 12 & IV & No looped & no looped & no looped & no looped & no looped & no looped & Looped \\
\hline 13 & M & Prominent above & Intermediate sunken & Intermediate sunken & Intermediate sunken & Intermediate sunken & Intermediate sunken & Sunken above \\
\hline 14 & ALV & $\begin{array}{ll}\text { Very } & \text { near } \\
\text { l.margin } & \end{array}$ & $1 / 3$ from leaf margin & $\begin{array}{l}1 / 4 \text { to } 1 / 5 \text { from leaf } \\
\text { margin }\end{array}$ & $1 / 2$ from leaf margin & Very near leaf margin & $1 / 3$ from leaf margin & $\begin{array}{l}1 / 4 \text { to } 1 / 5 \text { from leaf } \\
\text { margin }\end{array}$ \\
\hline 15 & VD & Present & Present & Present & Present & Present & Intmd & Present \\
\hline 16 & TUL & Present & Absent & Absent & Absent & Absent & Absent & Absent \\
\hline 17 & TDL & Present & Absent & Absent & Present & Absent & Present & Present \\
\hline 18 & TDM & Present & Absent & Present & Present & Present & Present & Present \\
\hline 19 & CUL & Dark green & Brownish green & Brownish green & Dark green & Dark green & Light green & Dark green \\
\hline 20 & CDL & Light green & Dark green & Light green & Dark green & Light green & Light green & Light green \\
\hline 21 & LM & Entire & Entire & Entire & Entire & Entire & Entire & Entire \\
\hline 22 & LT & Paperaceous & Membranaceous & Membranaceous & $\begin{array}{l}\text { Membranaceous- } \\
\text { paperaceous }\end{array}$ & Membranaceous & Membranaceous & Membranaceous \\
\hline 23 & LG & Absent & Absent & Absent & Present & Absent & Present & Absent \\
\hline 24 & PNLG & 0 & 0 & 0 & 4-6 pairs & 0 & 4-7 pairs & 0 \\
\hline 25 & LS & Bullate & Flat & Bullate & Flat & Flat & Flat & Bullate \\
\hline 26 & $\mathrm{TP}$ & Present & Absent & Present & Present & Present & Present & Present \\
\hline 27 & TCP & Light brown & Absent & Dark brown & Blackish & Greenish & Light brown & Light brown \\
\hline 28 & LFC & Reddish & Light brown & Greenish & Light brown & Light brown & Greenish & Light brown \\
\hline 29 & FS & Globose & Ellipsoid & Depressed globose & Globose & Globose & Ellipsoid & Globose \\
\hline 30 & FD & $2-2.7 \mathrm{~cm}$ & $1.5-2 \mathrm{~cm}$ & $1.7-1.8 \mathrm{~cm}$ & $3.9-4.8 \mathrm{~cm}$ & 4- $4.7 \mathrm{~cm}$ & $5-5.5 \mathrm{~cm}$ & $1.6-2.2 \mathrm{~cm}$ \\
\hline
\end{tabular}




\begin{tabular}{|c|c|c|c|c|c|c|c|c|}
\hline 31 & FL & $2.5-2.8 \mathrm{~cm}$ & $1.5-2 \mathrm{~cm}$ & $1.6-1.7 \mathrm{~cm}$ & $4-4.6 \mathrm{~cm}$ & $3.3-4 \mathrm{~cm}$ & $5.5-6 \mathrm{~cm}$ & $2-2.5 \mathrm{~cm}$ \\
\hline 32 & CYF & Light green & Light green & Dark green & Dark green & Light green & Yellow & Light green \\
\hline 33 & $\mathrm{CMF}$ & Light brown & Yellow & Light brown & Yellow & Brownish green & Light brown & Light brown \\
\hline 45 & $\mathrm{CDF}$ & Brown & black & Brown & black & Black & Brown & Brown \\
\hline 34 & FF & Intmd & Intmd & Non fleshy & Intmd & Non fleshy & Intmd & Non fleshy \\
\hline 35 & FG & Present & Absent & Absent & Absent & Absent & Absent & Absent \\
\hline 36 & WF & Absent & Present & Present & Present & Present & Present & Present \\
\hline 37 & FA & Depressed obtuse & Obtuse flat & Depressed obtuse & Obtuse flat & Depressed obtuse & Acute & Acute \\
\hline 38 & TYF & Present & Present & Present & Present & Present & Present & Present \\
\hline 39 & TDYF & Present & Dense & Not dense & Not dense & Present & Dense & Dense \\
\hline 40 & TMF & Present & Absent & Present & Present & Present & Present & Present \\
\hline 41 & TDMF & Not dense & Absent & Not dense & Not dense & Not dense & Dense & Dense \\
\hline 42 & TCYF & Dense hairy & Smooth & Dense hairy & Dense hairy & Lenticelate & Dense hairy & Dense hairy \\
\hline 43 & TCMF & Dark green & Absent & Dark green & Light green & Light green & Dark green & Dark green \\
\hline 44 & FS & Dense hairy & Smooth & Dense hairy & Dense hairy & Lenticelate & Dense hairy & Dense hairy \\
\hline 46 & MF & Wrinkle & Smooth & Drying hardwood & Drying hardwood & Smooth & Wrinkle & Drying hardwood \\
\hline 47 & SFC & Bowl shape & Campanulate & Bowl shape & Isodiametry & Bowl shape & Flatten triangular & Campanulate \\
\hline 48 & FCD & $4-5.5 \mathrm{~cm}$ & $2-2.5 \mathrm{~cm}$ & $1.6-1.7 \mathrm{~cm}$ & $4-5 \mathrm{~cm}$ & $4-4.8 \mathrm{~cm}$ & $3.8-4.3 \mathrm{~cm}$ & $2-2.5 \mathrm{~cm}$ \\
\hline 49 & LFCL & $2.5-3 \mathrm{~cm}$ & $2-2.5 \mathrm{~cm}$ & $1.6-1.7 \mathrm{~cm}$ & $4-5 \mathrm{~cm}$ & $4-4.8 \mathrm{~cm}$ & $3.8-4.3 \mathrm{~cm}$ & $2-2.5 \mathrm{~cm}$ \\
\hline 50 & NFCL & Lobes 4-5 & Lobes 4 & Lobes 4 & Lobes 4 & Lobes 3 & Lobes 4 & Lobes 4-5 \\
\hline 51 & SFCL & $\begin{array}{l}\text { Acuminate } \\
\text { triangular }\end{array}$ & Triangular wavy & Acute triangular & Acute triangular & Acute triangular & Acute triangular & Triangular wavy \\
\hline 52 & FCPMF & Flat & Half-covering & Flat & Flat & Whole covering & Reflexed & Whole covering \\
\hline 53 & FCPYF & Spreading & Flat & Flat & Flat & Half-covering & Spreading & $\begin{array}{l}\text { Half } \\
\text { Covering }\end{array}$ \\
\hline 54 & CLM & Wavy & Reflexed & Entire & Reflexed & Entire & Reflexed & reflexed \\
\hline 55 & $\mathrm{TFC}$ & Thin leafy & Thick leafy & Woody & Woody & Woody & Woody & Thick leafy \\
\hline 56 & TFC & Thick & Thick & Thick & Thick & Thick & Thick & Thick \\
\hline 57 & SFC & Hairy & Hairy & Coarsely lenticelate & Hairy & Coarsely lenticelate & Hairy & Smooth \\
\hline
\end{tabular}

Note: Chc.: Characters; BC:Bark color; BT: Bark texture; CS: Canopy shape; LS: Leaf shape; LL: Leaf length; LW:Leaf width; LA:Leaf apex; LB: Leaf base; PNV: Pair number of vein, V:Venation (main and lateral); LVP: Lateral venation pattern; IV: Intramarginal venation; M: Midrib; ALV; Anastomosing of lateral venation; VD; Vein domination; TUL: Trichome of upper leaf; TDL: Trichome of downside leaf; TDM: Trichome of downside midrib; CUL: Color of upper leaf; CDL: Color of downside leaf; LM: Leaf margin; LT:Leaf texture; LG:Leaf glands; PNLG: Pair number of leaf glands; LS: Leaf surface; TP: Trichome in petiole; TCP: Trichome color in petiole; LFC: Leaf flushing color; FS: Fruit shape; FD: Fruit diameter; FL: Fruit length; CYF: Color of young fruit; CMF: Color of mature fruit; CDF: Color of dry fruit; FF: Fruit flesh; FG: Fruit groove; WF: Wood of fruit; FA: Fruit apex; TYF: Trichome of young fruit; TDYF: Trichome density of young fruit; TMF: Trichome of mature fruit; TDMF: Trichome density of mature fruit; TCYF: Trichome color of young fruit; TCMF: Trichome color of mature fruit; FS: Fruit surface; MF: Mature fruit; SFS: Shape of fruit calyx; FCD: Fruit calyx diameter; LFCL: Large of fruit calyx lobes; NFCL: Number of fruit calyx lobes; SFCL: Shape of fruit calyx lobes; FCPMF: Fruit calyx position of mature fruit; FCPYF: Fruit calyx position of young fruit; CLM: Calyx lobes margin; TFC: Texture of fruit calyx; TFC: Thickness of fruit calyx; SFC: Surface of fruit calyx.; intmd: intermediate 